A N N A L E S

UNIVERSITATIS MARIAE CURIE-SKŁODOWSKA

LUBLIN - POLONIA

VOL. LXVII, 1

SECTIO G

2020

Uniwersytet Marii Curie-Skłodowskiej w Lublinie

ARTUR PIERZCHAŁA, JAKUB WIELGUS

artur.pierzchala@onet.eu; wielgusjakub@wp.pl

ORICD: 0000-0002-9924-6945; ORCID: 0000-0003-0955-749X

\title{
Sprawozdanie z Ogólnopolskiej Konferencji Naukowej pn. „Przychody oraz koszty według prawa podatkowego oraz bilansowego", Lublin, 5 kwietnia 2019 r.
}

Report from the National Scientific Conference "Revenues and Expenses According to Tax and Accounting Law", Lublin, April 5, 2019

W dniu 5 kwietnia 2019 r. na Wydziale Prawa i Administracji Uniwersytetu Marii Curie-Skłodowskiej w Lublinie odbyła się Ogólnopolska Konferencja Naukowa pn. „Przychody oraz koszty według prawa podatkowego oraz bilansowego”. Wydarzenie zostało zorganizowane przez Studenckie Koło Naukowe Prawa Podatkowego pod merytoryczną opieką Katedry Prawa Finansowego UMCS. Patronat honorowy objęli Naczelny Sąd Administracyjny, Krajowa Izba Doradców Podatkowych, Krajowa Izba Biegłych Rewidentów oraz Okręgowa Rada Adwokacka w Lublinie.

Konferencja była skierowana zarówno do studentów, jak i do młodych pracowników naukowych. Uczestniczyło w niej blisko trzydziestu prelegentów z dziesięciu ośrodków naukowych w kraju. Przedmiotem rozważań była problematyka przychodów oraz kosztów według prawa podatkowego i bilansowego. Celem zaś była analiza relacji prawa podatkowego i prawa bilansowego w zakresie ujmowania przychodów, kosztów oraz wyniku finansowego przedsiębiorcy. Prelegenci obradowali w ramach trzech paneli dyskusyjnych. Szeroki zakres tematyczny konferencji zagwarantował różnorodność w zakresie problematyki poruszanej w referatach. W niniejszym sprawozdaniu opisano wystąpienia, które wyróżniały się oryginalnością podjętych w nich problemów badawczych.

Referat inaugurujący obrady został wygłoszony przez mgr I. Morawską (Uniwersytet Ekonomiczny w Katowicach). W swoim wystąpieniu poruszyła ona 
kwestie odroczonego podatku dochodowego według MSR/MSSF w sprawozdaniach polskich spółek, poświęcając najwięcej uwagi regulacji MSR 12. Wystąpienie było wzbogacone o wyniki autorskich badań przeprowadzonych na podstawie sprawozdań finansowych spółek giełdowych za zakończone okresy sprawozdawcze w odniesieniu do omawianych w referacie kwestii. Metoda badawcza zastosowana przez referentkę pozwoliła na ukazanie doniosłości podatku odroczonego w odniesieniu do sytuacji majątkowo-finansowej tych spółek.

Następnie mgr A. Pazura (Istytut Nauk Prawnych PAN) poruszyła problematykę związaną z zaliczeniem do kosztów uzyskania przychodu podatku naliczonego na gruncie ustawy o podatku dochodowym od osób prawnych. Co do zasady podatek od towarów i usług nie może stanowić kosztów uzyskania przychodu, ale ustawa przewiduje pewne wyjątki. Obszarem rozważań były właśnie te szczególne przypadki. Prelegentka, odnosząc się do swojego doświadczenia zawodowego, wskazała na istotne problemy, z którymi musi się zmagać na co dzień jako doradca podatkowy.

Głos w dyskusji zabrał również mgr J. Czapczyński (Izba Komornicza w Lublinie). W swoim wystąpieniu dokonał analizy dogmatycznej statusu prawnego, finansowego i ustrojowego komornika sądowego w Polsce. Prelegent skoncentrował się na problematyce przychodów i kosztów uzyskiwanych w działalności egzekucyjnej. Impulsem do podjęcia rozważań dotyczących tego tematu było uchwalenie ustawy z dnia 22 marca 2018 r. o komornikach sądowych (Dz.U. 2018, poz. 771) oraz ustawy z dnia 28 lutego 2018 r. o kosztach komorniczych (Dz.U. 2018, poz. 770). Skutkiem wejścia w życie tych ustaw była zmiana sposobu działalności kancelarii komorniczych w całej Polsce.

Drugi panel dyskusyjny rozpoczął się od wystąpienia mgr M. Dąbrowskiej (Uniwersytet Łódzki). Rozważania prelegentki były skupione na wyjaśnieniu zakresu znaczeniowego pojęcia przychodu na gruncie prawa podatkowego i bilansowego. Referentka wskazała na występujące różnice wynikające $\mathrm{z}$ autonomiczności gałęzi prawa, co z kolei prowadzi do sporych wątpliwości interpretacyjnych.

Zainteresowanie wzbudziło także wystąpienie A. Pierzchały (UMCS), który poruszył kwestie rozliczania wydatków związanych z tzw. użytkiem mieszanym pojazdów lekkich w prowadzonej działalności gospodarczej jako koszt uzyskania przychodów. Impulsem do podjęcia tego tematu było uchwalenie 23 października 2018 r. ustawy o zmianie ustawy o podatku dochodowym od osób fizycznych, ustawy o podatku dochodowym od osób prawnych oraz niektórych innych ustaw (Dz.U. 2018, poz. 2159). Prelegent omówił oraz wyjaśnił nowe zasady rozliczania wydatków związanych z użytkowaniem pojazdów lekkich do celów zarówno gospodarczych, jak i prywatnych w prowadzonej przez podatnika działalności gospodarczej. Ponadto wykazał, że użytkowanie samochodu osobowego, którego wartość rynkowa przekracza ustawowe limity, prowadzi do powstania różnicy pomiędzy poniesionymi i ujętymi w księgach rachunkowych wydatkami a kwotą, 
która może stanowić koszt uzyskania przychodu. Referent dokonał też oceny nowej konstrukcji normatywnej, wskazując na korzyści i zagrożenia, jakie ona za sobą pociąga. Ważnym postulatem było wskazanie indeksowania wysokości omawianego limitu, określonego jako wartość nominalna, za pomocą jednego ze wskaźników gospodarczych, którym jest inflacja.

J. Piętka (UMCS) na podstawie literatury przedmiotu i orzecznictwa sądów administracyjnych podjął próbę zdefiniowania kosztów uzyskania przychodów na gruncie prawa podatkowego i bilansowego. W oparciu o konkretne stany faktyczne wskazał na obszar desygnatów pojęcia na gruncie obu gałęzi prawa. Z kolei A. Balicka (UMCS) poruszyła kwestię ksiąg rachunkowych, a w szczególności zasad ich rzetelnego i niewadliwego prowadzenia, konsekwencji ich nieprzestrzegania oraz ich znaczenia dla prawa podatkowego i bilansowego.

Mgr M. Zwierz (Uniwersytet Warszawski) skupiła się na tematyce zaliczenia kary umownej na poczet kosztów uzyskania przychodu. Celem wygłoszonego referatu było spojrzenie na instytucję o charakterze stricte cywilnoprawnym przez pryzmat dwóch regulacji prawnych z zakresu prawa podatkowego, tj. art. 23 ust. 1 pkt 19 ustawy z dnia 26 lipca 1991 r. o podatku dochodowym od osób fizycznych (Dz.U. 2019, poz. 1387 ze zm.) oraz art. 16 ust. 1 pkt 22 ustawy z dnia 15 lutego 1992 r. o podatku dochodowym od osób prawnych (Dz.U. 2019, poz. 865 ze zm.). Autorka wyszła z założenia, że nie ma przeciwwskazań do tego, aby poza enumeratywnie wymienionymi $\mathrm{w}$ powyższych ustawach wyjątkami podatnik posiadał w pewnych dopuszczalnych prawem sytuacjach możliwość zaliczenia kary umownej na poczet kosztów uzyskania przychodów. Prelegentka wskazała, dlaczego należy wykluczyć możliwość zaliczenia na poczet kosztów uzyskania przychodów kar umownych z tytułu wad dostarczonych towarów, wykonanych robót $\mathrm{i}$ usług oraz zwłoki $\mathrm{w}$ dostarczeniu towaru wolnego od wad albo zwłoki w usunięciu wad towarów albo wykonanych robót i usług.

Natomiast E. Tokarewicz (Uniwersytet Warszawski) poruszyła tematykę prezentów dla kontrahentów jako kosztów uzyskania przychodu. W wystąpieniu wskazała, że prezenty dla kontrahentów mogą być kosztem uzyskania przychodu, jeśli ich wartość jest niska i mają one charakter reklamowy. Inaczej jest jednak w przypadku prezentów, które nie są bezpośrednio związane z działalnością gospodarczą. Nie stanowią one wówczas kosztów uzyskania przychodów i nie można od nich odliczyć podatku od towarów i usług.

Wystąpienie P. Liwocha (Uniwersytet Ekonomiczny w Krakowie) było poświęcone alokacji bezpośrednich i pośrednich kosztów uzyskania przychodu według klucza przychodowego w kontekście zmian wprowadzonych ustawą z dnia 15 lutego 1992 r. o podatku dochodowym od osób prawnych, w której ustawodawca dokonał wyróżnienia dwóch źródeł przychodów: z zysków kapitałowych oraz z innych źródeł przychodów. Referent zauważył, że zmiana ta wywołuje różne wątpliwości, np. w zakresie odpowiedniego przypisania czy kompletności 
wyróżnienia wszystkich zdarzeń powodujących powstanie przychodu. W referacie zaprezentowane zostały przyczyny nowelizacji ujęcia źródła przychodów w oparciu o działania organów podatkowych oraz wyroki sądów administracyjnych. Ponadto została dokonana krytyczna analiza i ocena skutków funkcjonowania tej zmiany w obrocie prawnym.

Należy podkreślić, że wystąpienia uczestników konferencji wywoływały liczne dyskusje, które toczyły się i w trakcie, i po poszczególnych panelach.

Ze względu na duże zainteresowanie Ogólnopolską Konferencją pn. „Przychody oraz koszty według prawa podatkowego oraz bilansowego", różnorodność przygotowanych wystąpień i trafność głosów podjętych w trakcie dyskusji organizatorzy podjęli starania o przygotowanie publikacji pokonferencyjnej. 